\title{
An isotopically depleted, rejuvenated stage source component widely distributed in the Hawaiian plume
}

\author{
Frederick A. FreY', SHICHUN HUANG ${ }^{2}$, GUANGPING \\ $\mathrm{XU}^{3}$, Christopher DeFeliCE ${ }^{2}$, Clarisa DEL TORO \\ CONTRERAS $^{2}$
}

Department of Earth, Atmospheric and Planetary Sciences, Massachusetts Institute of Technology 2Department of Geoscience, University of Nevada Las Vegas ${ }^{3}$ Geochemistry Department, Sandia National Laboratories

A typical Hawaiian volcano has four growth stages: preshield, shield, post-shield, and rejuvenated. The first three growth stages usually complete within 1 Myrs, while the rejuvenated stage volcanism erupts about 0.5 to 2 Myrs after the end of the post-shield stage volcanism. Lavas from each growth stage are characterized by different elemental and isotopic compositions. Hawaiian rejuvenated stage lavas are typically highly alkalic and enriched in incompatible elements, but they have lower ${ }^{8} \mathrm{Sr} /{ }^{\circ 6} \mathrm{Sr}$ and higher ${ }^{{ }^{4} \mathrm{Nd}} \mathrm{Nd} /{ }^{14} \mathrm{Nd}$ and ${ }^{n} \mathrm{Hf} /{ }^{n} \mathrm{Hf}$ than shield stage lavas. It has been debated whether Hawaiian rejuvenated stage volcanism samples a mantle plume source component, or an isotopically depleted upper mantle component. Here we show by means of trace element characteristics that the mantle sources of Hawaiian rejuvenated stage lavas also contributed to some pre-shield and shield stage lavas. That is, the isotopically depleted rejuvenated stage mantle source is widely distributed within the Hawaiian mantle plume. During rejuvenated stage volcanism, this depleted mantle source melted to low degrees to form highly alkalic lavas. During the pre-shield and shield stage volcanism at some volcanoes, it melted to high degrees to form alkalic to tholeiitic lavas. 